\title{
Development of a Model for Assessing Vulnerability to Pollution of Groundwater in Fissured Aquifers: The Case of the Ehania Watershed (South-Eastern Côte d'Ivoire)
}

\author{
Brou Dibi $^{*}$, Arthur Brice Konan-Waidhet ${ }^{1}$, Valérie Plagnes ${ }^{2}$, Jean Biemi ${ }^{3}$ \\ ${ }^{1}$ UFR Environment/Jean Lorougnon Guedé University, Daloa, Côte d'Ivoire \\ ${ }^{2}$ UMR METIS/Sorbonnes University, Paris, France \\ ${ }^{3}$ UFR STRM/Felix Houphouet Boigny University, Abidjan, Côte d'Ivoire \\ Email: ^dibibrou2018@gmail.com, konanwab@yahoo.fr, valerie.plagnes@upmc.fr, jbiemi@yahoo.fr
}

How to cite this paper: Dibi, B., Konan-Waidhet, A.B., Plagnes, V. and Biemi, J. (2021) Development of a Model for Assessing Vulnerability to Pollution of Groundwater in Fissured Aquifers: The Case of the Ehania Watershed (South-Eastern Côte d'Ivoire). Journal of Environmental Protection, 11, $1-12$.

https://doi.org/10.4236/jep.2021.121001

Received: November 19, 2020

Accepted: January 11, 2021

Published: January 14, 2021

Copyright $\odot 2021$ by author(s) and Scientific Research Publishing Inc. This work is licensed under the Creative Commons Attribution International License (CC BY 4.0).

http://creativecommons.org/licenses/by/4.0/

\begin{abstract}
The protection of aquifers is a major concern for the authorities, especially in areas where there are large agro-industrial exploitations. The objective of this study is to define a new method of aquifer protection based on the characteristics of the structures of aquifers. The intrinsic vulnerability mapping method, PaPRI was used. It is a variant of the PaPRIKa method applied in karstic environment which has been adapted for its application in basement environment. This method uses three factors, including aquifer protection $(\mathrm{P})$, using the soil cover, the unsaturated zone and the thickness of the alteration layer, (R) for the rock type and (I) for infiltration which including slope and drainage density. PAPRI is a method based on the weighting of different factors. The results obtained show 4 classes that evolve from low vulnerability classes (5\% of the study area) to high and very high vulnerability classes (58\%) and average vulnerability classes (37\%). The classes of high and very high vulnerability, which indicate the zones that are very exposed to pollution, are more present in the central-northern part of the study area, with a few appearances towards the south. These zones could be related to topography due to the often very high slopes observed in the area. One of the advantages of this new method lies in the characterization of the alterations that strongly influence the migration of pollutants towards the water tables according to their nature and their thickness.
\end{abstract}

\section{Keywords}

Vulnerability to Pollution, Groundwater, PaPRI, Fissured Aquifer, Ehania 
Watershed, Côte d'Ivoire

\section{Introduction}

Groundwater resources play an important role in meeting water supply requirements due to anthropogenic activities and regional climate changes that reduce or render water resources unsuitable for consumption [1]. However, this groundwater is very vulnerable to pollution. The monitoring and actions to fight against possible contamination are among the most important concerns of water managers around the world [2]. However, the assessment of vulnerability to pollution is very important to understand the pollution of groundwater resources and how to better protect these resources [3] [4]. Given this situation, a project was developed to study the quality of groundwater resources. Several methods have been adopted to assess the vulnerability. There are DRASTIC [5], GOD [6], AVI [7], SINTACS [8] and many other small methods including the properties of the environment (DISCO, DRASTIC-fm, DRATIC-P, DRASTICLU) have been studied [9]. However, all these methods, although effective, only allow the evaluation of vulnerability to pollution in a punctual way, i.e. corresponding only to the area concerned by the study. The elaboration of a methodology for the mapping of protection perimeters appears essential. This is especially necessary in large agricultural production areas where contaminant inputs may be significant, as is the case in our study area, which contains large agro-industrial farms [10]. This method has already been the subject of several works in karstic environment through several versions, the last one being PaPRIKa [11] [12] [13]. In basement zones, it has also been the subject of several studies where it has produced important results [14] [15] [16]. In spite of these results, there are some shortcomings related to the effective consideration of the thickness of certain layers. The objective of this study is therefore to develop a methodology to map the protection zones of groundwater catchments in the midst of basement aquifers.

\section{Material and Methods}

\subsection{Study Area}

The Ehania watershed (Figure 1) site of this study is located in the extreme south-east of Côte d'Ivoire between longitudes $2^{\circ} 45 \mathrm{~W}$ and $3^{\circ} 05 \mathrm{~W}$ and latitudes $5^{\circ} 10 \mathrm{~N}$ and $5^{\circ} 45 \mathrm{~N}$. It covers about $342 \mathrm{~km}^{2}$.

The region has a tropical climate characterized by four seasons with two dry (large and small) and two wets (large and small). The geological formations vary from shale in the northern part to sedimentary formations in the south. These different types of geological formations indicate the existence of different aquifers which are aquifers in sedimentary formations (Quaternary and Tertiary), weathered and fractured aquifers. Concerning topography, the relief is very 


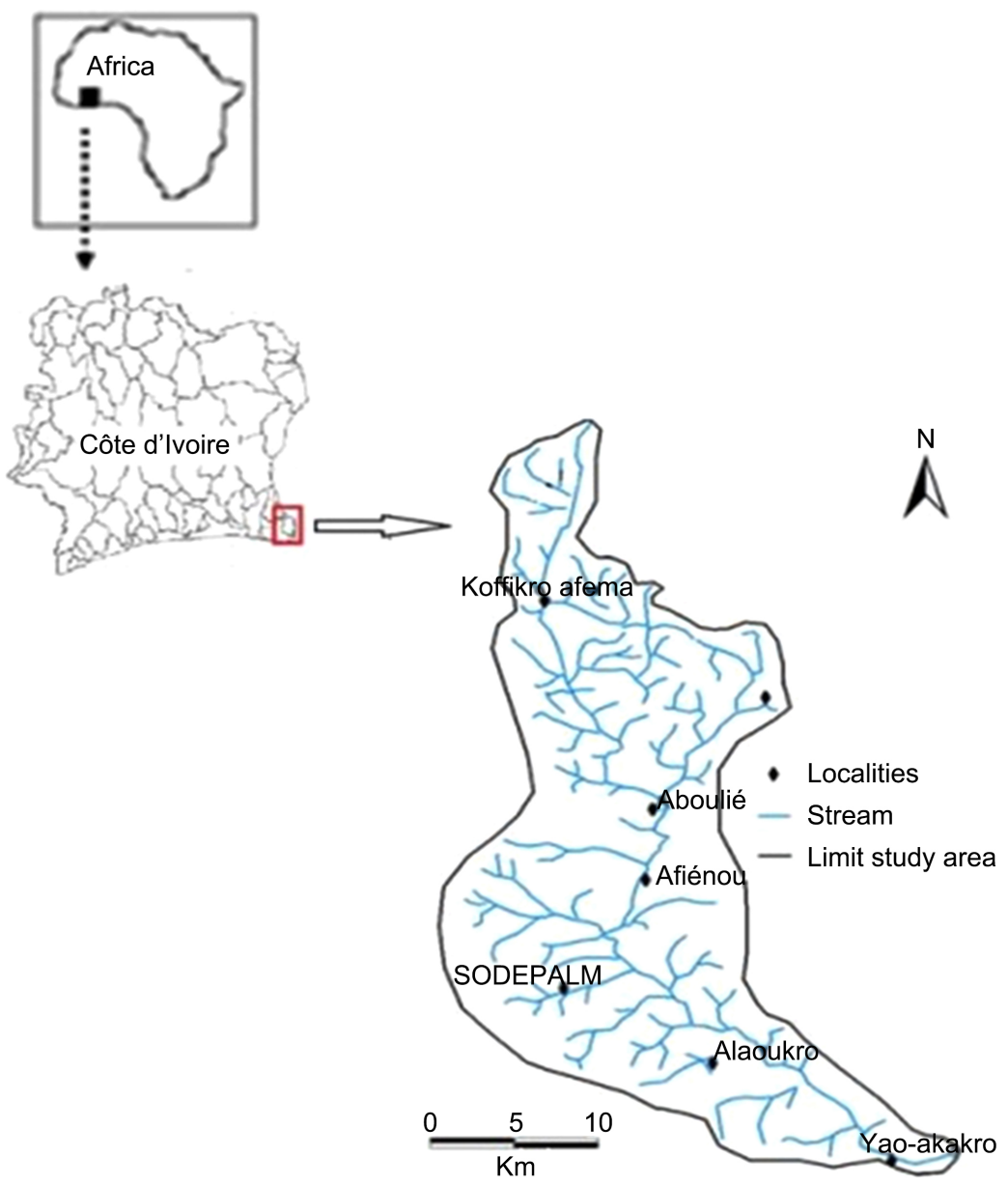

Figure 1. Location of study area.

rugged with altitudes generally ranging from 100 to $200 \mathrm{~m}$ to $400 \mathrm{~m}$. The hydrographic network which is an indicator of recharge is very dense in the North and less dense in the South. The soils are composed of reworked soil and sometimes with some portions of hydromorphic soil and pseudogley gley especially along the Ehania River.

The formatter will need to create these components, incorporating the applicable criteria that follow.

\subsection{Material}

Material used includes field equipment, cartographic, alphanumeric data and software. The field equipment is composed of the GPS and the piezometric probe to determine the coordinates of the points and to measure the water levels in the boreholes. The data used includes geological and soil maps and digital elevation model images of the study area. Alphanumeric data consisting of borehole data sheets and hydroclimatic data were also used. The processing of these data was done using ARCGIS software. It is a cartographic software that allowed the input of the databases and the realization of the different criterai maps. 


\subsection{Methods}

\subsubsection{Determination of Different Factors}

This method uses three criteria ( $\mathrm{P}, \mathrm{R}$ and $\mathrm{I}$ ) of which $\mathrm{P}$ represents the protection of aquifers, $R$ the type of rock and I which represents infiltration.

Factor P: It represents all the criteria that contribute to the protection of the water table from infiltration. It characterizes the ability to reduce the rate of pollutants or their rate of transfer to the water table. It depends mainly on the nature of the soil, the thickness of alteration and the thickness and fracturing of the unsaturated zone. Soil is the first layer that receives pollutants. It plays a first filtering bed preventing a certain number of pollutants from passing through it depending on its nature. A textural analysis was carried out in the area by [17] distinguished silty-clay, sandy-clay, clayey-sandy and sandy soils. In this study, the thickness is considered to be uniform and corresponding to the first level defined by [17] which varies from $0-10 \mathrm{~cm}$. The weathered layer is represented by its nature and thickness. It is shallower on massive grained rocks such as granites, where the first layer is generally sandy with high permeability and an indurated upper level but lies on a clayey-sandy horizon of very low permeability [18]. It is, however, very important on shales with a good clay content. Studies have shown that productivity increases with depth up to $30 \mathrm{~m}$ [19]. From this depth, productivity decreases with depth. On the basis of the values obtained in the zone, the following classes have been identified. The unsaturated zone represents the area between the soil surface and the water level in the aquifer. It remains variable from one zone to another. However, in most cases, in addition to alteration formations, it closes the fissured rocks. It differs from the thickness of the alteration by taking into account the fractured section. As for the thickness of the unsaturated zone, it was determined from piezometric levels and corresponds to the difference between the altitude of the water point considered and the static water level in the structure.

Factor R: This factor designates the aquifer Reservoir characterized by the lithological nature and fracturing of the nature of rock [20]. It is to be appreciated by considering the lithological nature which is made of either schists or granitoids. In addition to lithology, fracturing plays a primordial role, especially regional accidents or mega fractures. They serve as underground corridors. The fracturing is represented by the fracture density which is obtained from the fracture map. Depending on their density, size, arrangement in the environment and physical properties, fractures considerably modify the hydraulic properties of basement rocks [21] [22].

Factor I: This factor concerns infiltration conditions. This infiltration is a function of several parameters such as topographic slope and drainage density. The slope is one of the most important parameters that condition infiltration. The steeper the slope, the lower the infiltration. Thus, the lower the slope, the greater the infiltration [23]. As for drainage density, the lower the drainage density, the greater the infiltration and vice versa [24]. 


\subsubsection{Weighting of Factors}

For the development of the different criteria, the method of Saaty [25] based on pair-wise comparison was adopted to determine the different weights. The procedure is based on the following steps:

- comparison of the relative importance of all the elements belonging to the same level of the hierarchy, taken in pairs, in relation to the element of the level immediately above;

- configuration of a reciprocal square matrix formed by the evaluations of the ratios of the weights $(\mathrm{K} \times \mathrm{K})$, $\mathrm{K}$ being the number of elements compared. We get this way: $a=a i j$ with $a j j=1$ and $a j i=1 / a i j$ (reciprocal value) where $a$ is the value of each factor and $i$ and $j$ constituting the rows and columns. The eigenvectors and the weighting coefficients are then calculated from their geometric mean [10].

On this basis, the factor weights are determined from a series of pairwise comparisons taking into account their importance in establishing the potentiality map [26]. This importance is determined on a numerical scale as shown in Table 1.

The values from this table of verbal and numerical expression of the relative importance of a pair of factors were then integrated into a calculation of eigenvector (Equation (1)) and weighting coefficient (Equation (2)) for each parameter to determine the weighting coefficient of each criterion or factor (Tables 2-4) [10].

$$
V_{p_{i}}=\sqrt[n]{\prod_{i=1}^{n} N_{i}}
$$

$V_{p_{i}}=$ Eigenvector of each factor; $N_{i}=$ Value of each factor. The weighting coefficient $\left(W_{i}\right)$ of each factor is determined as follows:

$$
W_{i}=\frac{V_{p_{i}}}{\sum_{i=1}^{n} V_{p_{i}}}
$$

\subsubsection{Determination of the Vulnerability Index}

The calculation of the global vulnerability index allows the estimation of the contours of the protection zones. It was done on the basis of the DISCO method [27] which was designed to adapt to fissured environments by taking into account the relative importance of the different criteria as proposed by the DISCO and PaPRIKa methods. According to [11], the most important factor could be infiltration (I), since a large infiltration would be responsible for a high risk of degradation of groundwater quality in these locations. The weights were calculated using Saaty's [25] paired comparison method. Indeed, the vulnerability of an aquifer system is not the result of several factors but the result of several protective layers whose effects accumulate [28]. The criteria taken into account are $\mathrm{P}$ (protection of the aquifer), $\mathrm{R}$ (nature of the rock) and I (infiltration) (Equation (3)). Table 5 presents the weights resulting from this approach. 
Table 1. Verbal and numerical expression of the relative importance of a modified pair of factors [15].

\begin{tabular}{cc}
\hline $\begin{array}{c}\text { Verbal expression of the relative importance of one } \\
\text { criterion in relation to another }\end{array}$ & Notes \\
Less important & $1 / 3$ \\
Slightly less important & $1 / 2$ \\
Same importance & 1 \\
Slightly very important & 2 \\
Very important & 3 \\
\hline
\end{tabular}

Table 2. Table of weights for $\mathrm{R}$ factor.

\begin{tabular}{ccc}
\hline Criteria & Eigenvector & Weighting coefficient \\
\hline Fracturing density & 1.73 & 0.60 \\
Nature of Rock & 1.24 & 0.40 \\
\hline
\end{tabular}

Table 3. Table of weights for P factor.

\begin{tabular}{ccc}
\hline Criteria & Eigenvector & Weighting coefficient \\
\hline ZNS & 1.82 & 0.40 \\
Weathering layer & 1.51 & 0.35 \\
Soil & 1.22 & 0.25 \\
\hline
\end{tabular}

Table 4. Table of weights for I factor.

\begin{tabular}{ccc}
\hline Criteria & Eigenvector & Weighting coefficient \\
\hline Slope & 1.73 & 0.60 \\
Drainage density & 1.24 & 0.40 \\
\hline
\end{tabular}

Table 5. Table of criteria weights.

\begin{tabular}{ccc}
\hline Factor & Eigenvector & Weighting coefficient \\
\hline Infiltration (i) & 1.59 & 0.50 \\
Protection (p) & 0.79 & 0.25 \\
Reservoir (r) Nat & 0.79 & 0.25 \\
\hline
\end{tabular}




$$
\mathrm{Vg}=\mathrm{iI}+\mathrm{pP}+\mathrm{rR}
$$

With I, $\mathrm{P}$ and $\mathrm{R}$ represent the different factors and $\mathrm{i}, \mathrm{r}$ and $\mathrm{p}$ are the weights of these factors.

Equation (3) becomes Equation (4):

$$
\mathrm{Vg}=0.5 \mathrm{I}+0.25 \mathrm{P}+0.25 \mathrm{R}
$$

\subsubsection{Determination of Pollution Vulnerability Classes}

The different classes of vulnerability to pollution were determined from five colors used to represent the degree of vulnerability at each point in the study area. Thus, blue represents the class of very low index, green for the low index class, yellow for the average class, brown for class 3 indicating a high index and red for class 4 indicating a very high index [16] [29] (Table 6).

\section{Result and Discussion}

\subsection{Result}

\subsubsection{Analysis of the Results of the Various Factors}

The factor $\mathrm{P}$ (weighting $=0.35$ ) map (Figure $2(\mathrm{a})$ ) representing protection remains dominated by the strong and very strong class, which covers 80 percent of the study area. This class considered to be strong protection is found over almost the entire study area where the geological formations are generally shale. These classes are due to a significant weathering layer which is assumed to be richer in clay. As for the low to average protection classes (20\%), they are observed in the shallows, especially for the low protection class. For the average protection class, its presence is noted in the contact zones between the basement and sedimentary formations as well as on generally granitic formations.

Factor R plays a role that represents the least important factor in the assessment (Weighting Coefficient $=0.2$ ) in terms of aquifer protection. For factor R, the greater the index, the higher the vulnerability. The analysis of the results of this factor (Figure 2(b)) shows that the basin is dominated by the class with the highest protection (44\%) which occurs in the central part and in the central-northern part. In these areas, the aquifer rock is shale. As for the average and low protection classes, which alone cover more than $50 \%$ of the Study Area, they occur in the extreme north, south and central-eastern part of the study.

Table 6. Pollution vulnerability classes [29].

\begin{tabular}{cccc}
\hline Vulnerability Index & Classes & Vulnerability & Color \\
\hline $3.20-4.00$ & 4 & Very high & Red \\
$2.40-3.19$ & 3 & High & Browm \\
$1.60-2.39$ & 2 & Average & Yellow \\
$0.80-1.59$ & 1 & Low & Green \\
$00-0.79$ & 0 & Very Low & Blue \\
\hline
\end{tabular}




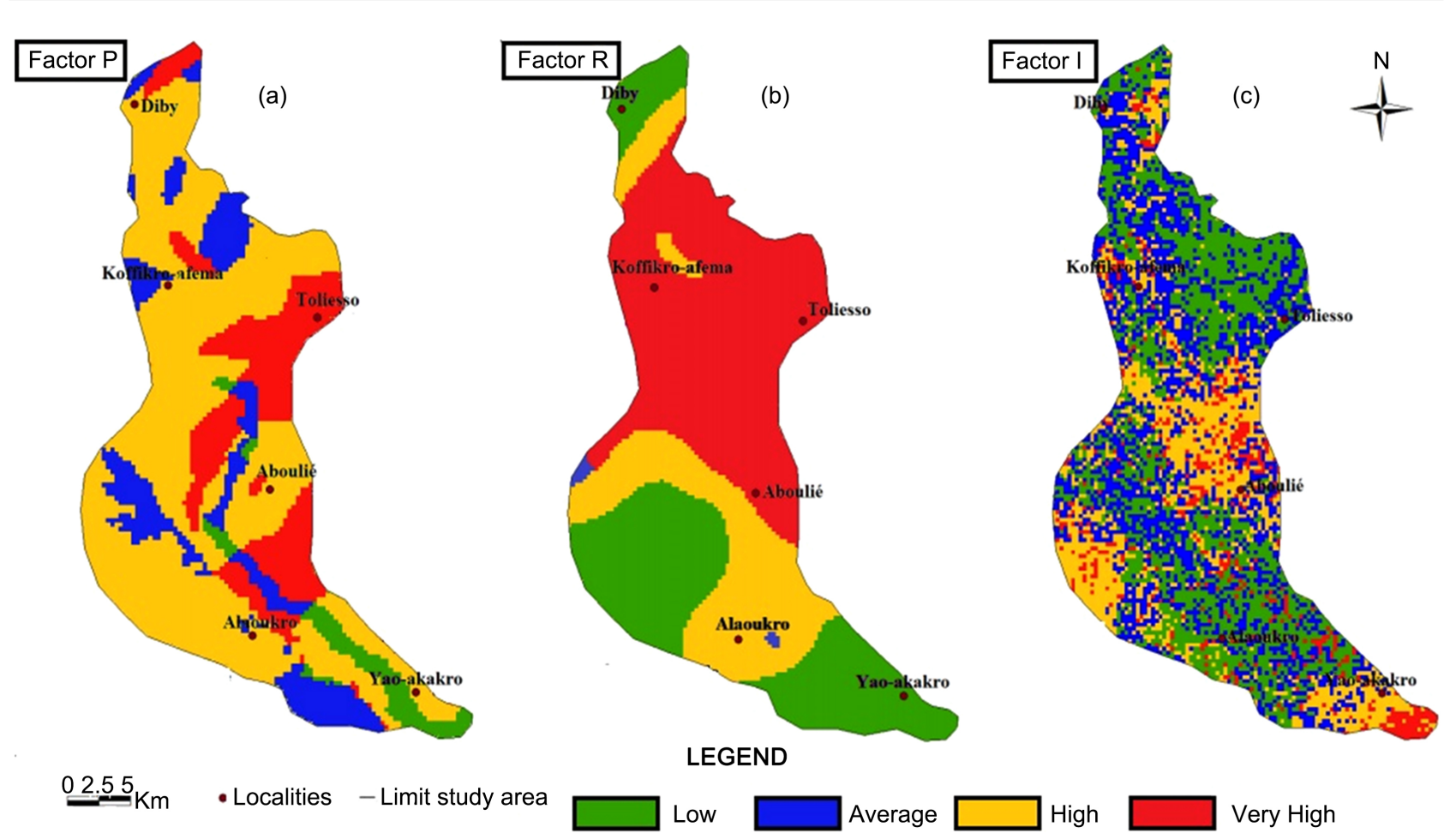

Figure 2. Maps of differents factors: (a) Factor P (Protection); (b) Factor R (Reservoir); (c) Factor I (Infiltration).

The analysis of factor I (Figure 2(c)) shows the 4 classes of vulnerabilities identified. This factor, which reflects the capacity of the basin to resist or favour infiltration, remains dominated by the low and average infiltration classes which are found throughout most of the study area in areas where the river system is relatively dense. In these areas, slopes are significant. The low infiltration classes cover $39 \%$ of the surface and occur globally over the entire study area. As for the high and very high vulnerability classes, they are more present in the southern and central zones with a few weak occurrences in the north where the low slopes are accompanied by low drainage density.

\subsubsection{Map of Vulnerability to Pollution}

The combination of all factors resulted in the intrinsic vulnerability map using the PaPRI method. This map (Figure 3) allowed to distinguish 4 classes. Low and medium vulnerability zones occupy about $42 \%$ of the total area of the study area and are generally observed on shale or granitic formations with generally moderate slopes. However, they are more present in the north-central sector with a few isolated pockets in the central part. The high vulnerability class is by far the most important class in the study area. It covers $47 \%$ of the study area. It is reported in all sectors where average slopes with sedimentary formations and shales coexist. While it is found over almost the entire study area, its presence is more pronounced in the center and south. As for the very strong vulnerability class, which covers $11 \%$ of the study area, it is generally found in the south and central-western part of the study area with an appearance in the north in the locality of Diby. In these zones, the formations are generally composed of shale 


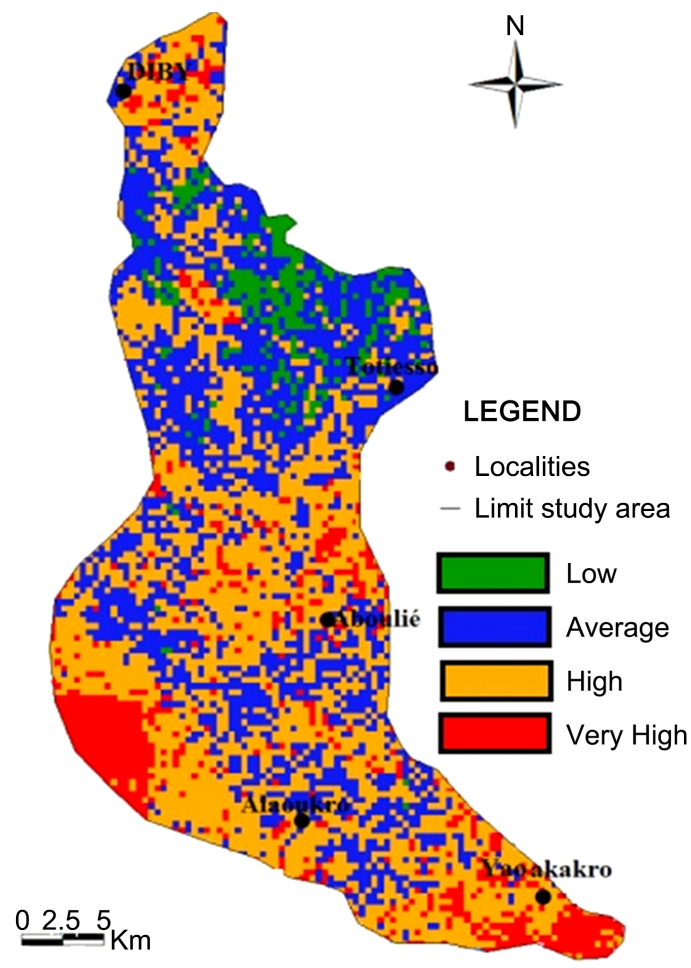

Figure 3. Map of vulnerability to pollution.

and slopes are low. These zones are considered areas to be monitored. In these zones, implementation of any work that could cause damage to the water table and water quality must be studied beforehand to assess the measures to be taken according to the importance and objective of the operation.

\subsection{Discussion}

The PaPRI method presents itself as a new method for mapping the intrinsic vulnerability of aquifers in fissured media. Like the PaPRIKa method, the PaPRI method, specially designed for intrinsic vulnerability assessment, is based on structural factors and hydraulic behaviours in accordance with the concepts of [30] developed for karsts. The P factor that characterizes the protection of the water table includes all the factors capable of acting as the first curtain that can prevent pollutants from reaching the water table and fracturing. The capacity of protection of the Ehania watershed lies in the existence not only of metamorphic formations, but also in the importance of alteration layers. The nature of the unsaturated zone, in addition to the alteration layer, still contains some of the fissured rocks and enhances the protection of the underlying resources. The combination of all these criteria added to a soil layer whose thickness remains variable could explain the strong protective capacity of the aquifers. The importance of factor $\mathrm{R}$ depends on its ability to allow water to pass through it. Thus, the harder or more resistant to the rock, the less water can pass through it. At the level of basement formations, criterion $\mathrm{R}$ is strongly dependent on fracturing and alteration that affects the hydrodynamic properties of the reservoir. As for 
the Factor I map, it is highly dependent on slope and drainage density. However, slope remains the most important parameter. Indeed, according to the work of [10], in areas with low slopes and high permeability values, groundwater availability varies from good to excellent. This means that in areas of low slopes, water remains in contact with the soil longer and facilitates its infiltration compared to areas of high slopes. The water is then quickly drained away, as indicated by the work of [24] who showed that the higher the slopes and the greater the drainage density, the lower the probability of water infiltration to the water table and vice versa.

\section{Conclusion}

At the end of this vulnerability assessment study using the new PaPRI method, important results were obtained. It made it possible to evaluate the intrinsic vulnerability by combining several criteria which were grouped into 3 factors according to their role in the transfer of and potential pollutants that flow with it. The results obtained during this study made it possible to identify the different zones of sensibility to pollution and to determine the areas to be protected. In priority, thus, $58 \%$ of the area was identified as "vulnerable" zones, grouping together the classes of strong and very strong requiring protection. These zones can be observed over almost the entire study area with a concentration in the south-west, central and southern sectors of the study area. The efficacity and robustness of this method lie not only in the importance of the number of criteria but also, and above all, in taking into account the thicknesses of these layers.

\section{Acknowledgements}

We thank the International Foundation for Science (IFS) for funding this research and the technical partners who facilitated the analysis in the laboratory. We also thank villager's community for its availability and understanding.

\section{Conflicts of Interest}

The authors declare no conflicts of interest regarding the publication of this paper.

\section{References}

[1] Thirumalaivasan, D., Karmegam, M. and Venugopal, K. (2003) AHP-Drastic: Software for Specific Aquifer Vulnerability Assessment Using DRASTIC Model and GIS. Environmental Modelling \& Software, 18, 645-656. https://doi.org/10.1016/S1364-8152(03)00051-3

[2] Aksever, F., Karagüzel, R. and Mutlutürk, M. (2015) Evaluation of Groundwater Quality and Contamination in Drinking Water Basin: A Case Study of the Senirkent-Uluborlu Basin (Isparta-Turkey). Environmental Earth Sciences, 73, 1281-1293. https://doi.org/10.1007/s12665-014-3483-3

[3] Gavrilescu, M. (2009) Emerging Processes for Soil and Groundwater Cleanup: Potential Benefits and Risks. Environmental Engineering and Management Journal, 9, 1293-1307. https://doi.org/10.30638/eemj.2009.190 
[4] Hao, L., Huang, L., Wang, W. and Zhang, H. (2011) Evaluation of the Impact of Planting Structure on Water Resources. Environmental Engineering and Management Journal, 10, 899-903. https://doi.org/10.30638/eemj.2011.126

[5] Aller, L., Lehr, J.H., Petty, R. and Bennett, T. (1987) DRASTIC-A Standardized System to Evaluate Groundwater Pollution Potential Using Hydrogeologic Setting. Journal of the Geological Society of India, 29, 23-37.

[6] Foster, S. (1987) Fundamental Concepts in Aquifer Vulnerability, Pollution Risk and Protection Strategy. In: Van Duijvenbooden, W. and Van Waegeningh, H.G., Eds., Vulnerability of Soil and Groundwater to Pollutants, Committee on Hydrological Research, The Hague, 69-86.

[7] Van Stempvoort, D., Ewert, L. and Wassenaar, L. (1993) Aquifer Vulnerability Index: A GIS-Compatible Method for Groundwater Vulnerability Mapping. Canadian Water Resources Journal, 18, 25-37. https://doi.org/10.4296/cwrj1801025

[8] Civita, M. (1994) The Maps of Groundwater Vulnerability to Pollution: Theory and Practice. Quaderni di Tecniche di Protezione Ambientale, Pitagora. (In Italian)

[9] Dibi, B., Kouamé, K.I., Konan-Waidhet, A.B., Savane, I., Biemi, J., Nedeff, V. and Lazar, G. (2012) Impact of Agriculture on the Quality of Groundwater Resources in Peri-Urban Zone of Songon (Côte d'Ivoire). Environmental Engineering and Management Journal, 11, 2173-2182. https://doi.org/10.30638/eemj.2012.271

[10] Doumouya, I., Dibi, B., Kouamé, K.I., Saley, B., Jourda, J.P., Savane, I. and Biemi, J. (2012) Modelling of Favourable Zones for the Establishment of Water Points by Geographical Information System (GIS) and Multicriteria Analysis (MCA) in the Aboisso Area (South-East of Côte d'Ivoire). Environmental Earth Science, 67, 17631780. https://doi.org/10.1007/s12665-012-1622-2

[11] Kavouri, K., Plagnes, V., Tremoulet, J., Dörfliger, N., Reijiba, F. and Marchet, P. (2011) PaPRIKa: A Method for Estimating Karst Resource and Source Vulnerability-Application to the Ouysse Karst System (Southwest France). Hydrogeology Journal, 19, 339-353. https://doi.org/10.1007/s10040-010-0688-8

[12] Huneau, F., Jaunat, J., Kavouri, K., Plagnes, V., Rey, F. and Dörfliger, N. (2013) Intrinsic Vulnerability Mapping for Small Mountainous Karst Aquifers, Implementation of the New PaPRIKa Method to Western Pyrenees (France). Engineering Geology, 161, 81-93. https://doi.org/10.1016/j.enggeo.2013.03.028

[13] Ollivier, C., Lecomte, Y., Chalikakis, K., Mazzilli, N., Danquigny, C. and Emblanch, C. (2018) A QGIS Plugin Based on the PaPRIKa Method forKarst Aquifer Vulnerability Mappingby. Groundwater, 57, 201-204. https://doi.org/10.1111/gwat.12855

[14] Dibi, B., Plagnes, V., Konan-Waidhet, A.B. and Savané, I. (2015) Définition d'une méthodologie de dimensionnement des zones de protection des ouvrages de captages d'eaux souterraines en zone de socle. Cas de la zone test du bassin versant d'Ehania (Sud-est de la Côte d'Ivoire). Vingtièmes journées techniques du Comité Français d'Hydrogéologie de l'Association Internationale des Hydrogéologues. Aquifères de socle: Le point sur les concepts et les applications opérationnelles, La Roche-sur-Yon, $16 \mathrm{p}$.

[15] Mangoua, M.J., Konan, K.S., Kouamé, K.I., Zougrou, N.N., Kouassi, K.L., Savane, I. and Biemi, J. (2018) Assessment of Vulnerability to Groundwater Pollution in the Department of Tiassalé (South of Côte d'Ivoire). EWASH \& TI Journal, 2, 46-54.

[16] Kamenan, Y.M., Mangoua, O.M.J., Dibi, B., Georges, S.E., Kouassi, K.L. and Kouassi, K.A. (2020) Assessment of Vulnerability to Groundwater Pollution in the Lobo Watershed at Nibéhibé (Central-West, Côte d'Ivoire). Journal of Water Resource and Protection, 12, 657-671. https://doi.org/10.4236/jwarp.2020.128040 
[17] Dabin, B., Leneuf, N. and Riou, G. (1960) Carte pédologique de la Côte d'Ivoire au 1/2.000.000. Notice explicative, ORSTOM, 39.

[18] Wyns, R., Gourry, J.C., Baltassat, J.M. and Lebert, F. (1999) Caractérisation multiparamètre des horizons de subsurface $(0-100 \mathrm{~m})$ en contexte de socle altéré. Colloque GEOFCAN: Géophysique des sols et des formations superficielles. BRGM, INRA, IRD, UPMC, 21-22 septembre, Orléans, France, Actes du 2e colloque, 105-110.

[19] Dibi, B. (2008) Cartographie des sites potentiels d'implantation des points d'eau dans le département d'Aboisso (Sud-Est de la Côte d'Ivoire): Apport du SIG et de l'analyse multicritère. Thèse unique de Doctorat, Université de Cocody, Abidjan, 164.

[20] Dörfliger, N. and Plagnes, V. (2010) Cartographie de la vulnérabilité des aquifères karstiques guide méthodologique de la méthode PaPRIKa [Mapping the Vulnerability of Karst Aquifers. Guidelines of the Method PAPRIKa]. Rapport BRGM RP57527-FR, 100.

[21] De Dreuzy, J.-R. (2000) Analyse des propriétés hydrauliques des réseaux de fractures. Discussion des modèles d'écoulement compatibles avec les principales propriétés géométriques. Thèse de Doctorat, Univ. Rennes 1, France, 217.

[22] Darcel, C. (2002) Corrélations dans les réseaux de fractures: Caractérisation et conséquences sur les propriétés hydrauliques. Hydrologie. Université Rennes 1, 223.

[23] Sinan, M. and Razack, M. (2008) An Extension to the DRASTIC Model for Assessing Groundwater Vulnerability to Pollution: Application to the Haouz Aquifer of Marrakech (Morocco). Environmental Geology, 57, 349-363.

https://doi.org/10.1007/s00254-008-1304-2

[24] Prasad, R.K., Mondal, N.C., Pallavi, B., Nandakumar, M.V. and Singh, V.S. (2008) Deciphering Potential Groundwater Zone in Hard Rock through the Application of GIS. Environmental Geology, 55, 467-475. https://doi.org/10.1007/s00254-007-0992-3

[25] Saaty, T.L. (1977) A Scaling Method for Priorities in Hierarchical Structures. Journal of Mathematical Psychology, 15, 234-281. https://doi.org/10.1016/0022-2496(77)90033-5

[26] Eastman, R.J., Kyem, P.A.K. and Toledano, J. (1993) A Procedure for Multiple-Objective Decision Making in GIS under Conditions of Conflicting Objectives. EGIS 93, Genoa, Vol. 1, 438-447.

[27] OFEFP/OFEG (2003) Délimitation des zones de protection des eaux souterraines en milieu fissuré. Guide Pratique, 83.

[28] Vernoux, J.-F., Wuilleumier, A. and Dörfliger, N. (2007) Délimitation des bassin versant des captages et de leur vulnérabilité vis a vis des pollutions diffuses. Guide méthodologique, BRGM, 70.

[29] Durand, L. (2012) Cartographie de la Vulnérabilité du Système Karstique des Eaux Belles (Haute-Savoie) et étude de son Fonctionnement. Master 2 Sciences de l'univers, Environnement, Ecologie. Université Pierre et Marie Curie, École des Mines de Paris \& École Nationale du Génie Rural des Eaux et des Forêts, Parcours Hydrologie Hydrogéologie, 45.

[30] Mangin, A. (1975) Contribution à l'étude hydrodynamique des aquifères karstiques [Contributions to the Hydrodynamics of Karst Aquifers]. Thèse, Université Dijon, France, 124. 